\title{
Fault indicators on the Russian market
}

\author{
Maksim Vladimirovich Borodin ${ }^{1,{ }^{*}}$, Tatyana Anatolievna Kudinova ${ }^{2}$, and Khasanov Shamil Rashidovich ${ }^{3}$ \\ ${ }^{1}$ Department "Power Supply", Orel State Agrarian University named after N.V. Parakhin, Orel, Russia \\ ${ }^{2}$ Department "Linguistics and Humanities", Orel State Agrarian University named after N.V. Parakhin, Orel, Russia \\ 3"Power Supply of Industrial Enterprises", Kazan State Power Engineering University, Kazan, Russia
}

\begin{abstract}
The article indicates the relevance of using fault indicators. Various models and manufacturers of fault indicators are presented on the Russian market. The analysis of the characteristics of various fault indicators was produced. At present, the most suitable domestic device for electric grid companies in Russia, which allows determining the open and short circuit on power lines, as well as indicating the location of the fault, is a fault indicator C134B of the ANTRAKS R\&D\&M Co, Ltd. The market analysis of fault indicators in Russia will allow specialists of design organizations, personnel of electric grid companies and other specialists to reduce the time spent on searching for information on fault indicators.
\end{abstract}

\section{Introduction}

The authors' works [1-11] indicate that rapid location of faults on power lines can significantly accelerate the restoration of power supply to consumers and reduce the number of attending personnel, eliminating the faults. In case of a fault on a power line, it is necessary to determine the place of wire breakage or the location of failed power equipment more accurately; in turn, it will allow the personnel to reduce the time on locating and eliminating the fault on a power line quicker.

The authors [12-20] indicate that falling of trees on power lines, breakdowns of insulators and other causes of faults greatly complicate the work of attending personnel of electric grid companies. Most often, there are no devices for monitoring power lines; so the place of insulator breakdowns and other faults must be determined visually. It takes a lot of time and leads to a long disconnection of consumers. In this regard, there is a need for the use of special equipment to detect an open and a short on power lines, as well as to indicate the location of the faults.

One of the devices that can do the above mentioned things is a fault indicator (FI). Depending on the purpose and design, the FIs are installed in the switchgear unit, on the overhead power line support, or directly on the phase line wire. The use of FIs can significantly reduce the time and cost of locating and eliminating faults in branched distribution networks.

\section{Research methodology}

In Russia, on the market of fault indicators, FI models of various manufacturers are widely presented. At the same time, the characteristics of FIs of various manufacturers differ from each other; it, in turn, affects their effectiveness.

The personnel, dealing with the selection of FIs, spend considerable time on it, since FIs, presented on the Russian market, have different characteristics and prices. To increase the efficiency of the selection of FIs, it is necessary to analyze their characteristics.

Analysis of the FIs, presented on the Russian market, will be made according to the following parameters:

- minimum detection current for single phase-to-ground faults;

- determination of current direction;

- presence of internal memory;

- radio communication range;

- channel used for alarm annunciation;

- fault indication;

- FI power supply;

- FI battery life;

- data transfer unit power supply;

- the largest range for line-to-line faults;

- system of fault location;

- etc.

\section{Results and their discussion}

Fault indicators of eight companies were presented on the Russian market. Appearance, models and manufacturers of fault indicators are presented in table 1 .

\footnotetext{
* Corresponding author: maksimka-borodin@yandex.ru
} 
Table 1. Models and manufactures of fault indicators.

\begin{tabular}{|c|c|}
\hline $\begin{array}{c}\text { Model, } \\
\text { (manufacturer) }\end{array}$ & $\begin{array}{c}\text { Appearance of the } \\
\text { device }\end{array}$ \\
\hline FI-C13B, (Antraks) & \\
\hline $\begin{array}{l}\text { JYZ-HW V2.0, } \\
\text { (Four-Faith) }\end{array}$ & \\
\hline $\begin{array}{c}\text { AMKA-single } \\
\text { phase-to-ground } \\
\text { fault-18, (AIZ } \\
\text { Lytkarino) }\end{array}$ & \\
\hline FLA3.1VL, (INION) & \\
\hline $\begin{array}{l}\text { Overhead line fault } \\
\text { indicator (OLFI), } \\
\text { (Relematika) }\end{array}$ & \\
\hline $\begin{array}{l}\text { Sicam FSI, } \\
\text { (Siemens) }\end{array}$ & \\
\hline $\begin{array}{l}\text { Smart Navigator } \\
\text { (HORSTMANN) }\end{array}$ & \\
\hline $\begin{array}{l}\text { ASTRON-8080, } \\
\text { (ASTRON) }\end{array}$ & \\
\hline
\end{tabular}

All of the above mentioned FIs are placed on the phase wire of the power line. Externally, product designs are almost identical. They are a sealed flask, inside which, depending on the manufacturer, there may be a battery, an electronic circuit, a set of LED indicators.

The installation of a FI can be carried out both on a disconnected power line using a truck crane, and on a power line under voltage using appropriate insulating rods. FIs usually operate as a group of three to six devices with information exchange with a data collection and transmission unit (DCTU).

DCTU provides communication in the appropriate protocol with the remote server. All FI models, presented in the table, are used as an alarm annunciation channel the GSM / GPRS channel. The FI power supply is provided by built-in batteries; individual manufacturers have implemented the function of recharging the FI from power lines.
The characteristics of FIs of various manufacturers, presented on the Russian market, are shown in table 2 .

The FIs, presented in Table 2, have different characteristics. So, the minimum detection current is provided by Anthrax $\mathrm{FI}-\mathrm{Cl} 3 \mathrm{~B}$, it is $0.5 \mathrm{~A}$; determination of current direction is available in Four-Faith FI- JYZHW V1.0, in Relematika FI-OLFI and Anthrax FI-C13B; presence of internal memory is available in Anthrax FICl3B; the HORSTMANN FI Smart Navigator has the longest battery life which is equal to 20 years; the smallest wire diameter for installation has the HORSTMANN FI; the largest range for line-to-line fault is available in Anthrax $\mathrm{FI}-\mathrm{Cl} 3 \mathrm{~B}$ and ranges from 20 to $2000 \mathrm{~A}$; the system of fault location is available in Siemens FI- Sicam FSI, INION FI- FLA3.1VL, Relematika FI-OLFI and Anthrax FI-Cl3B.

\section{Conclusions}

Based on the presented analysis, we can conclude that at the moment, the most suitable domestic device for the Russian grid companies to determine the open and short circuit on power lines, as well as to indicate the location of the fault, is a fault indicator C134B of the ANTRAKS R\&D\&M Co, Ltd.

The market analysis of fault indicators in Russia will allow specialists of design organizations, personnel of electric grid companies and other specialists to reduce the time spent on searching for information on fault indicators. 
Table 2. Characteristics of FIs, presented on the Russian market.

\begin{tabular}{|c|c|c|c|c|c|c|c|c|c|c|}
\hline $\begin{array}{l}\mathrm{N} \\
\mathrm{o}\end{array}$ & Parameter & Siemens & $\begin{array}{c}\text { AIZ } \\
\text { Lytkarino }\end{array}$ & \multicolumn{2}{|c|}{ IIORSTMANN } & INION & ASTRON & Relematika & Antraks & $\begin{array}{l}\text { Four- } \\
\text { Faith }\end{array}$ \\
\hline 1 & 2 & 3 & 4 & 5 & 6 & 7 & 8 & 9 & 10 & 11 \\
\hline 1 & Model of FI & Sicam FS & $\begin{array}{l}\text { AMKA- } \\
\text { single } \\
\text { phase-to- } \\
\text { ground } \\
\text { fault-18 } \\
\text { UHLl }\end{array}$ & $\begin{array}{c}\text { Smart } \\
\text { Navigat } \\
\text { or }\end{array}$ & $\begin{array}{c}\text { Smart } \\
\text { Navigato } \\
\text { r } 2.0\end{array}$ & FLA3.1VL & $\begin{array}{c}\text { ASTRO } \\
\text { N -8080 } \\
\text { UHL1 }\end{array}$ & OLFI & B 34 & $\begin{array}{c}\text { JYZ- } \\
\text { FF } \\
\text { V2.0 }\end{array}$ \\
\hline 2 & $\begin{array}{l}\text { Minimum } \\
\text { detection } \\
\text { current for } \\
\text { single phase-to- } \\
\text { ground faults, A } \\
\end{array}$ & $5 \ldots 1500$ & 120 & 100 & 100 & $4 \ldots 1500$ & $120 \ldots 630$ & $120 \ldots 600$ & $20 \ldots 2000$ & $3 \ldots 800$ \\
\hline 3 & $\begin{array}{l}\text { Range for line- } \\
\text { to-line fault, } \mathrm{A}\end{array}$ & 5 & 3 & 50 & 5 & 5 & 20 & 20 & 0,5 & 3 \\
\hline 4 & $\begin{array}{l}\text { Determination } \\
\text { of current } \\
\text { direction for } \\
\text { single phase-to- } \\
\text { ground fault }\end{array}$ & No & No & No & No & No & No & Yes & Yes & No \\
\hline 5 & $\begin{array}{l}\text { Presence of } \\
\text { internal memory }\end{array}$ & No & No & No & No & No & No & No & Yes & No \\
\hline 6 & $\begin{array}{l}\text { Radio } \\
\text { communication } \\
\text { range, } \mathrm{m}\end{array}$ & No data & No & 30 & 30 & 50 & No data & 50 & 200 & $\begin{array}{l}\text { No } \\
\text { data }\end{array}$ \\
\hline 7 & $\begin{array}{l}\text { Alarm } \\
\text { annunciation } \\
\text { channel } \\
\end{array}$ & $\begin{array}{l}\text { GSM/ } \\
\text { GPRS }\end{array}$ & $\begin{array}{l}\text { GSM/ } \\
\text { GPRS }\end{array}$ & $\begin{array}{l}\text { GSM/ } \\
\text { GPRS }\end{array}$ & $\begin{array}{l}\text { GSM/ } \\
\text { GPRS }\end{array}$ & $\begin{array}{l}\text { GSM/ } \\
\text { GPRS }\end{array}$ & GSM & $\begin{array}{l}\text { GSM/ } \\
\text { GPRS }\end{array}$ & $\begin{array}{l}\text { GSM/ } \\
\text { GPRS/ } \\
\text { SMS }\end{array}$ & $\begin{array}{l}\text { GSM/ } \\
\text { GPRS }\end{array}$ \\
\hline 8 & \begin{tabular}{|l|} 
Temperature \\
range, ${ }^{0} \mathrm{C}$
\end{tabular} & $-40 \ldots+70$ & $-40 \ldots+70$ & $\begin{array}{c}- \\
40 \ldots+85 \\
\end{array}$ & $-40 \ldots+85$ & $-40 \ldots+70$ & $-40 \ldots+60$ & $-40 \ldots+80$ & $\begin{array}{c}- \\
55 \ldots+85 \\
\end{array}$ & $\begin{array}{c}- \\
40 \ldots+70 \\
\end{array}$ \\
\hline 9 & $\begin{array}{l}\text { Wire Diameter } \\
\text { for installation, } \\
\mathrm{mm}\end{array}$ & $5-42$ & $5-42$ & 8-29 & $8-29$ & $5-42$ & $5-35$ & $10-42$ & $5-42$ & $5-42$ \\
\hline 10 & Fault indication & $\begin{array}{c}\text { LEDs on the } \\
\text { FI }\end{array}$ & $\begin{array}{c}\text { Blinker and } \\
\text { LEDs on the } \\
\text { FI }\end{array}$ & $\begin{array}{c}\text { LEDs on } \\
\text { the FI }\end{array}$ & $\begin{array}{c}\text { LEDs on the } \\
\text { FI }\end{array}$ & $\begin{array}{l}\text { Blinker and } \\
\text { LEDs on the } \\
\text { FI }\end{array}$ & $\begin{array}{c}\text { LEDs on the } \\
\text { FI }\end{array}$ & $\begin{array}{c}\text { LEDs on } \\
\text { the FI }\end{array}$ & \begin{tabular}{|l} 
LEDs on \\
the FI, \\
blinker on \\
the data \\
transfer unit
\end{tabular} & $\begin{array}{c}\text { LEDs on } \\
\text { the FI }\end{array}$ \\
\hline 11 & FI power supply & From battery & From battery & $\begin{array}{l}\text { From } \\
\text { battery }\end{array}$ & From battery & $\begin{array}{c}\text { With current in } \\
\text { the line of more } \\
\text { than } 20 \mathrm{~A} \\
\text { works from } \\
\text { power lines }\end{array}$ & From battery & $\begin{array}{c}\text { From } \\
\text { battery }\end{array}$ & \begin{tabular}{|c|} 
From \\
battery
\end{tabular} & $\begin{array}{c}\text { From } \\
\text { battery }\end{array}$ \\
\hline 12 & $\begin{array}{l}\text { Declared hattery } \\
\text { life, years }\end{array}$ & 10 & $>10$ & 20 & $\begin{array}{c}\text { Recharged } \\
\text { from power } \\
\text { lines }\end{array}$ & $\begin{array}{c}\text { Recharged from } \\
\text { power lines }\end{array}$ & 7 & 8 & 10 & 10 \\
\hline 13 & $\begin{array}{lr}\text { Data } & \text { transfer } \\
\text { unit } & \text { power } \\
\text { supply } & \end{array}$ & $\begin{array}{l}\text { Battery } \\
\text { powered, } \\
\text { solar } \\
\text { recharged }\end{array}$ & $\begin{array}{c}\text { Battery } \\
\text { powered, } \\
\text { solar } \\
\text { recharged }\end{array}$ & \begin{tabular}{|c|} 
Battery \\
powered, \\
recharged \\
from power \\
lines \\
\end{tabular} & \begin{tabular}{|c|} 
Battery \\
powered, \\
recharged \\
from power \\
lines \\
\end{tabular} & $\begin{array}{c}\text { Battery } \\
\text { powered, } \\
\text { recharged from } \\
\text { power lines }\end{array}$ & \begin{tabular}{|c} 
Battery \\
powered, \\
recharged \\
from power \\
lines \\
\end{tabular} & No data & \begin{tabular}{|c|} 
Battery \\
powered, \\
recharged \\
from power \\
lines \\
\end{tabular} & $\begin{array}{c}\text { Battery } \\
\text { powered, } \\
\text { solar } \\
\text { recharged }\end{array}$ \\
\hline 14 & $\begin{array}{l}\text { System of fault } \\
\text { location }\end{array}$ & Yes & No & No & No & Yes & No & Yes & Yes & No \\
\hline
\end{tabular}

\section{References}

[1] N.S. Sorokin, Improving the Operation Efficiency of Electrical Networks with Voltage of $6-35 \mathrm{kV}$ by Monitoring the Parameters of the Electrical Network, National University of Life and Environmental Sciences of Ukraine, Series: Technics and Energy of the Agro-industrial Complex, 209-2, 92-95 (2015)
[2] M.V. Borodin, N.S. Uryupin, Justification of Energy-efficient Cross-section of Power Lines with Voltage Deviations of $\pm 5 \%, \pm 10 \%$, Bulletin of Nizhny Novgorod Institute of Engineering and Economics 2, 81, 20-29 (2018)

[3] Yu.N. Glybina, R.P. Belikov, I.N. Fomin, Analysis of the Types and Amount of Faults in Electric 
Networks of Voltage Class 6-10KV, Agrotechnics and Power Supply 3, 16, 43-49 (2017)

[4] A.V. Vinogradov, V.E. Bolshev, A.V. Vinogradova, M.V. Borodin, A.V. Bukrecv, Technical and Economic Methods for Increasing the Efficiency of Rural Consumers' Power Supply Systems, Bulletin of Don Agricultural Science 3, 47, 59-67 (2019)

[5] M. Borodin, A. Psarev, T. Kudinova, R. Mukhametzhanov, Improving Power Quality by Calculating Voltage Losses, E3S Web of Conferences, 1041 (2019)

[6] I. Fomin, R. Belikov, V. Zelyukin, E.V. Mikhailova, Improvement of Power Supply Reliability by Means of Remote Control of the Automatic Repeated Switching-on of Sectionalizing Circuit-Breakers, E3S Web of Conferences, 01042 (2019)

[7] A. Vinogradov, V. Bolshev, A. Vinogradova, T. Kudinova, M. Borodin, A. Selesneva, N. Sorokin, A System for Monitoring the Number and Duration of Power Outages and Power Quality in $0.38 \mathrm{kV}$ Flectrical Networks, P. Vasant, I. Zelinka, G.W. Weber (eds) Intelligent Computing \& Optimization, ICO 2018, Advances in Intelligent Systems and Computing 866, 1-10 (2019)

[8] S.M. Astakhov, R.P. Belikov, State and Ways to Improve the Performance of Distribution Networks in the Agro-industrial Complex, Bulletin of OrelSAU 29, 2, 106-108 (2011)

[9] E.I. Gracheva, O.V. Fedorov, Forecasting Reliability of Electrotechnical Complexes of Inplant Electric Power Supply Taking Into Account Low-Voltage Electrical Apparatuses, 2019 International Conference on Industrial Engineering, Applications and Manufacturing, ICIEAM 2019, 8743057 (2019)

[10] E.I. Gracheva, R.R. Sadykov, R.R. Khusnutdinov, A.N. Alimova, Reliability and Layout of LowVoltage Switchgears for Internal Shop Power Supply, Bulletin of Kazan State Power Engineering University 11, 1 (41), 3-9 (2019)

[11] E.I. Gracheva, O.V. Naumov, Z.M. Shakurova, Information Parametric Characteristics of Reliability of Low-Voltage Switching Devices of Industrial Complexes, Bulletin of Kazan State Power Engineering University 3, 39, 27-33 (2018)

[12] M.V. Borodin, A.A. Dorozhkina, A.E. Semenov, Methodology for the Selection and Determination of the Most Effective Measuring Transformer for a Substation, News of Higher Educational Institutions of the Black Earth Region 4, 58, 58-68 (2019)

[13] S.M. Astakhov, A.S. Scherbakov, M.V. Borodin, Data Processing Unit of a Remote Control System for Operating Modes of a Distribution Network of $10 \mathrm{kV}$, Power supply and Safety, Collection of materials of the II International Exhibition-Internet Conference, 18-21 (2008)
[14] V.A. Chernyshov, A.E. Semenov, R.P. Belikov, V.E. Bolshev, M. Jasinski, M.S. Garifullin, The of Extending Drone Piloting Autonomy When Monitoring the Technical Condition of 6-10 kv Overhead Power Lines, E3S Web of Conferences 2019, 02010 (2019)

[15] R.P. Belikov, Remote Search and Repair of Faults in Electric Networks 6 (10) $\mathrm{kV}$, Physics and Modern Technologies in the Agro-Industrial Complex, Materials of the XI All-Russian Youth Conference of Young Scientists, Students and Schoolchildren with International Participation. Ministry of Agriculture of the Russian Federation, FSBEI HE "Orel State Agrarian University named after N.V. Parakhin", 373-375 (2020)

[16] I.N. Fomin, R.P. Belikov, Development of an Algorithm for Remote Monitoring of Disconnection of a Sectionalizing Power Line Circuit Breaker, Bulletin of Agricultural Science 4, 73, 98-105 (2018)

[17] A.V. Vinogradov, V.I. Zelyukin, A.E. Semenov, A.V. Vinogradova, The Effectiveness of the Use of Automatic Re-Inclusion in Comparison With the Causes of Damage to the OHL-10 kV, Bulletin of Don Agricultural Science 2, 42, 74-80 (2018)

[18] A.V. Vinogradov, V.A. Chernyshov, A.E. Semenov, A.O. Moroz, A Method for Monitoring the Technical Condition of Elements of an Overhead Power Line, Agrotechnics and Power Supply 3, 3, 64-68 (2014)

[19] A.V. Vinogradova, A.I. Psarev, Prohibition of Automatic Switching-on of a Reserve for a Short Circuit in a Reserved Section of a $0.4 \mathrm{kV}$ Power Line, Bulletin of Nizhny Novgorod Institute of Engineering and Economics 4, 107, 44-54 (2020)

[20] A.V. Vinogradov, A.N.Vasiliev, V.E. Bolshev, A.V. Vinogradova, T.A. Kudinova, N.S. Sorokin, N.V. Gruntovich, Methods of reducing the power supply outage time of rural consumers, Renewable Energy and Power Supply Challenges for Rural Regions (Series "Premier reference source", Hershey, PA, USA, 370-392, 2019) 